DOI 10.15393/j10.art.2016.2622

\title{
ПРИЯОЖЕНИЕ $1^{*}$
}

\section{Письмо П. А. Матвеева к Ф. М. Достоевскому}

\author{
Г. Самара \\ Многоуважаемьй \\ Өедорг Михайловичъ,
}

Изданіе Гражданина представляеть такое отрадное восполненіе того пробпла въ нашей періодческой печати, который оставили преждевременно угасшіе Заря и Беспда, что положительно грпино не сказать Вамъ слова сочувствія и привпта на тернистомь пути нашего печатнаго слова.

Настоящій органб партіи, которую принято называть славянофиль-

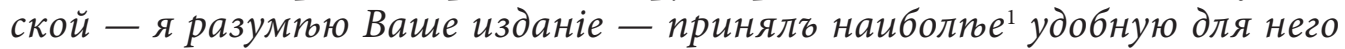
форму - именно газетную. Почтенный Николай Николаевичъ Страховъ, хотя самғ въ жизни далеко не практикъ, <л. 1> но зампчательно впрно указалъ, что у насъ въ публикю идуть толстые журналы западническаго направленія, а газеты славянофильскаго въ под<т>вержденіе этого заключенія къ своему обозрпнію нашей печати, въ Зарп, онъ сослался на мудраго стари, который столь успьшно западничая въ От. Запискахъ, славянофильствуеть своимъ «Голосомъ».

Печальный конецъ Зари еще лучше подтвердиль эту истину, въ ней же высказанную. Въ настоящее время едва ли возможно прочное и усппшное существованіе толстаго славянофильскаго органа, но газета вполнть и совершенно возможна и даже въ такой полужурнальной формп, какъ еженедпльникъ. Вашему «Гражданину» я положительно предсказываю скорый, несомнюнный и большой усппхъ. Да не смущаеть Васъ малая иифра настоящихъ подпищиковъ, о которой я сужу по тому № что ${ }^{4}$ стоитъ на получаемомъ мной экземплярп. Даже въ нашей Самарг, среди интеллигенціи коей по сіе время царить Зло свптсловской духъ "Дюла» распространяется вкусъ къ чтенію "Гражданина» и мнюь положительно истрепали и засалили тьь №№, гдп помпщены превосходные очерки Мещерскаго «Наши Бисмарки»․

${ }^{1}$ Далее было: а. для (незачеркнуто); б. сію

${ }^{2}$ на вписано.

3 даже вписано.

${ }^{4}$ Было: который - исправлено автором: что

${ }^{5}$ Былл: наши

${ }^{6}$ На полях слева примечание П. А. Матвеева: такъ много оказалось охотниковъ прочесть эту мастерскую сатиру на нбкоторые замашки и нравы нашей бюрократіи. - 
Этимь чтеніемъ $^{8}$ мпстное общество, хотя тайкомб, но положительно наслаждается - <л. 1 об.> явное сочувствіе «Гражданину» по сіе время однако еще ${ }^{10}$ считается предосудительнымъ - ересью такъ сказать. - ${ }^{11}$

Впрочемъ не будемъ слишком корить публику за ее предубпжденіе противъ Вашей газеты, прошлогодняя редакція нпкоторыми своими промахами сама этому не мало содюйствовала, давая оружіе противъ себя рыиарямг свистопляски въ родпь Буренина и Суворина.

Изъ статей Гражданина за нынтиній годъ я не совспмъ доволенъ только статьями о судебной ребормп и присяжныхъ. Вы совершенно впрно ${ }^{12}$ чувствуете, что нашъ новый судебный порядокъ заключаеть въ себю много фальши, но по моему мнюнію ошибка Ваша заключается въ томб, что Вы судите его не съ той точки зрпнія, какъ бы сльдовало ${ }^{13}$. Очевидно ${ }^{14}$ Вы его слишкомь мало знаете. Кромп того, значеніе суда присяжныхъ гораздо шире и многостороннпе ${ }^{15}$ чюмь Вы его понимаете - я сужу по Вашей статьюь ${ }$ эо $^{16}$ можеть быть и не есть ${ }^{17}$ лучшая организація суда для правильнаго ргошенія дюль (Коллегія коронныхъ судей, образованныхъ спеціалистовъ въ этомь отношеніи благонадежнте), но во всякомг случап прекрасная школа общественнаго развитія для народа. Какъ ни полезно распространеніе въ народг грамотности, но ограничивать сферу развитія народа школой и книжкой нельзя - это обстоятельство отнюдь не слпдуеть опускать изъ вида органу такого направленія, какъ Гражданинъ.

Возьмите напр. наши Волостные Суды, о которыхъ Гражданинъ за прошльй годъ помпстиль нпскклько дпльныхъ статей, какъ съ ними быть и что нужно для ихъ улучшенія? <л. 2>

Нгокоторые изб нашихъ Бисмарковб, быстро пишущзих и соображующихъ составителей всевозможныхъ ${ }^{18}$ проектовъ, полагаютб ${ }^{19}$ что для этого необходимо обязательно засадить ${ }^{20}$ вспхъ мужиковъ за букварь. Чпмъ болюе грамотныхъ на волости тпмғ благообразнюе Волостной Судъ, ${ }^{21}$

\footnotetext{
7 Этимъ вписано.

${ }^{8}$ Далее было: какъ

${ }^{9}$ Было: положительное - исправлено автором: положительно

${ }^{10}$ однако еще вписано.

11 - ересью такъ сказать. вписано.

${ }^{12}$ вьрно вписано.

${ }^{13}$ Далее было: и кромь того

${ }^{14}$ Очевидно вписано.

${ }^{15}$ Бълло очибочно: многостороннее (ред. испр.)

${ }^{16}$ Далее было: вовсе не

${ }^{17}$ можетъ быть и не есть вписано.

${ }^{18}$ Было очибочно: всбвозможныхъ (ред. испр.)

${ }^{19}$ Далее было: д

${ }^{20}$ Далее было: обязательно

${ }^{21}$ Далее было: утверждають
} 
разсуждають 22 они. Такъ, но ${ }^{23}$ не всегда, между тюмъ мнг, какъ много лить изучаюшему практику Волостныхъ Судовъ и народное обычное право, достовпрно извпстно, что Волостные Судьи бывшіе присяжными, тамъ, гдп Окружные Судь не молотять дпла какъ горохъ, ${ }^{24}$ отправляя правосудіе на почтовыхъ, а ведуть проиесст истово, не торопясь и толково, гдп прокуратура и адвокатура не кошунствують надь совпстью и словомь, тамь говорю я бывшіе присяжные 25 становясь за тюмб Волостными Судьями отправляють эту послюднюю ${ }^{26}$ обязанность толковпе и лучше обнаруживають больше уваженіе къ личности судящихся и высказывають ${ }^{28}$ стремленіе установить ${ }^{29}$ сколько нибудь ильлесообразнье суда. Отсутствіе, совершенное отсутствіе послюднихъ капитальньй недостатокъ нашихъ Вол. Судовъ. Это судъ свободный отъ всякихъ формъ всп говорять разомъ: судьи, судяніеся и свидптели. ${ }^{31}$ Происходить неимп<ю>щее опредюленнаго начала и кония, а въ этомъ хаосп человпкъ не привычный потеряеть всякую путеводную нить и бюжить оттуда съ больной головой. Неудобство такого порядка начинають сознавать мужички побьвавшіе въ присяжныхъ, а это смюю Васъ увприть вовсе не бездплица.

При семъ посылаю Вамғ мою программу нар. юрид. обычаевъ, желательно что бь печать обратила серьозное вниманіе нашего земства на изданіе Сборниковъ этихъ обычаевъ, это одна изб сущ,ественныхъ потребностей дня.

Искренне и глубоко Васъ уважаюшій

П. Матвиевъ <л. 2 об.>

Мой усердныцй поклонъ Н. Н. Страхову, которьй смпю думать не совспмь забыль меня, хотя давно уже мнп ничего не пишеть, послю кониа Зари я оть него не импль ни строки. - ${ }^{33}$

22 разсуждаютъ вписано.

23 Далее было: но

${ }^{24}$ какъ горохъ, вписано.

25 тамъ говорю я бывшіе присяжные вписано.

${ }^{26}$ Было ошибочно: посльднею (ред. испр.)

27 лучше вписано.

${ }^{28}$ высказываютъ вписано.

${ }^{29}$ Далее было: болье

${ }^{30}$ Было ошибочно: цъльсообразные (ред. испр.)

${ }^{31}$ Была запятая - исправлено автором на точку.

32 Было: происходитъ - исправлено автором: Происходить

${ }_{33}$ Запись: Мой усердный поклонъ Н. Н. Страхову, который смъю думать не совсъмъ забылъ меня, хотя давно уже мнъ ничего не пишетъ, посль конца Зари я отъ него не имъль ни строки. - сделана слева на полях л. 2 об. 
Извините что пишу такъ небрежно, причина этого крайній недосугъ<.> Здюиній Судъ на столько заваленъ работой, что только въ ночное время можно найти минуту досуга для чтенія и письма подобнаго настоящему. ${ }^{34}$

Адресъ мой: въ г. Самару Члену Окружнаго Суда Павлу Александровичу Матвиеву. ${ }^{35}$

\section{Текстодогическая справка}

Источник текста: РО ИРЛИ. Ф. 100. № 29773. 2 л.

Публикуется впервые.

\section{ПРИМЕЧАНИЯ}

* Исследование выполнено по гранту РГНФ № 14-34-01245a2.

С. 71. ...угасшіе Заря и Беспда... - «Заря» и «Беседа» - учено-литературные журналы.

«Заря», примыкавшая к славянофильскому направлению (ред.-изд. В. Кашпирев), издавалась в Санкт-Петербурге с 1869 по 1872 гг. Журнал полемизировал с «Отечественными Записками», «Делом», «Вестником Европы». Несмотря на участие в журнале Н. Я. Данилевского, В. И. Ламанского, К. Н. Бестужева-Рюмина, М. П. Погодина, В. Щебальского, А. Д. Градовского, Н. Н. Страхова, В. Богишича, Д. И. Иловайского, Ф. М. Достоевского, А. Ф. Писемского, В. Крестовского, Ф. И. Тютчева, А. Н. Майкова, А. Фета, Б. Алмазова и др., число подписчиков доходило лишь до 700 (см.: Энциклопедическій словарь Брокгауза и Ефрона: в 82 т. + 4 доп. СПб.: Семеновская Типолитографія (И. А. Ефрона), 1894. T. XII (23). C. 313).

«Беседа» ежемесячно издавалась С. А. Юрьевым в Москве в 1871-1872 гг. без предварительной цензуры. Журнал был направлен на то, чтобы «содъйствовать по мъръ его силъ къ тому, чтобы идеальная сторона была присуща духу русскаго народа и чтобы всъ великія истины, выработанныя западными народами, стали достояніемъ русскаго сознанія и русской жизни; но чтобы въ то же время и самостоятельность русской мысли не была уничтожена». Задача журнала - «содъйствовать подъему философскаго духа въ нашемъ обществъ и распространенію общечеловъческихъ свъдъній, изученію нашей народной жизни, по возможности, безъ всякой предвзятой мысли, изученію жизни славянскихъ народовъ, какъ братьевъ общей для насъ съ ними славянской семьи, съ судьбами которой неразрывно связана наша будущность, и сравнительному изученію нашей жизни съ жизнью прочихъ европейскихъ народовъ». В журнале принимали участие и публиковались Н. П. Аксаков, В. А. Елагин, А. И. Кошелев, Н. П. Колюпанов, А. Е. Нос, Н. И. Соловьев, Т. И. Филиппов, Г. В. Есипов, Н. И. Костомаров, А. Д. Градовский, О. Ф. Миллер, А. Ф. Писемский, А. Н. Плещеев, И. Н. Якунин. Второй год для журнала, когда шире и яснее обозначились его стремления, оказался сложным. Издателем было объявлено о его закрытии (см.: Энциклопедическій словарь Брокгауза и Ефрона: в 82 т. + 4 доп. СПб.: Семеновская Типолитографія (И. А. Ефрона), 1891. Т. IIIa (6). С. 630-631).

${ }^{34}$ Перевернутая запись: Извините что пишу такъ небрежно, причина этого крайній недосугъ<.> Здъшній Судъ на столько заваленъ работой, что только въ ночное время можно найти минуту досуга для чтенія и письма подобнаго настоящему. - сделана вверху л. 2 об.

${ }^{35}$ Перевернутая запись: Адресъ мой: въ г. Самару Члену Окружнаго Суда Павлу Александровичу Матвъеву. - сделана вверхул. 1 об. 
С. 71. Почтенный Николай Николаевичъ Страховъ... - Н. Н. Страхов (1828-1896) русский философ, публицист, литературный критик, член-корреспондент Петербургской АН, действительный статский советник. С 1861 по 1884 годы Страхов работал в журналах «Время» и «Эпоха», которыми руководил Ф. М. Достоевский. В 1869-1872 гг. стал фактическим редактором и главным сотрудником журнала «Заря» (см.: [5, 194-195]).

С. 71. ...нъ сослался на мудраго стария, который столь усппшно западничая въ От. Запискахъ, славянофильствуеть своимъ «Голосомъ»... - Имеется в виду Андрей Александрович Краевский (1810-1889) - журналист, приобретший у П. П. Свиньина в 1839 году права на издание «Отечественных Записок», прекративших свое существование из-за недостатка подписчиков (см.: [1, 483-484]). «Отечественные Записки»- журнал, основанный историком и писателем Свиньиным, издавался в Санкт-Петербурге с 1818 года, a с 1820 года - ежемесячно. При А. А. Краевском в журнале появились многочисленные отделы по истории, словесности, художеству, домоводству, сельскому хозяйству. В отделе словесности публиковались произведения М. Ю. Лермонтова, А. В. Кольцова, Е. П. Растопчиной, В. А. Соллогуба, кн. В. Ф. Одоевского, В. И. Даля, И. И. Панаева и др. В отделе критики и библиографии со второй половины 1839 по 1846 гг. работал В. Г. Белинский, одновременно с которым в «Отечественные Записки» стали писать А. И. Герцен, Т. Н. Грановский, П. Н. Кудрявцев, В. П. Боткин и др. В 1859 году «Отечественные Записки» из «журнала учено-литературного» были преобразованы в «журнал учено-литературный и политический». С сентября 1860 года до конца 1866 года соредактором Краевского и главным руководителем журнала был С. С. Дудышкин. С января 1868 года фактическими редакторами журнала сделались Н. А. Некрасов, М. Е. Салтыков и Г. З. Елисеев, арендовавшие журнал у Краевского; после смерти Некрасова (1877) в число редакторов-пайщиков вошел Н. К. Михайловский. С апреля 1876 года Салтыков считался и ответственным редактором. После выхода 4-й книжки 1884 года «Отечественные Записки» были запрещены Совещанием министров внутренних дел, народного просвещения, юстиции и обер-прокурора Св. Синода, на основании временных правил о печати 1883 года (см.: Энциклопедическій словарь Брокгауза и Ефрона: в 82 т. + 4 доп. СПб.: Семеновская Типолитографія (И. А. Ефрона), 1891. Т. XXII (43). С. 414-416).

В 1863 году А. А. Краевский основал в Петербурге собственную политическую и литературную газету «Голос». Газета занимала исключительное положение в журналистике по числу подписчиков, масштабности издания, влиянию на читающую публику. В начале у издания было около 4000 подписчиков, в 1877 году газета расходилась в 22632 экземплярах, а под конец ее существования эти цифры выросли еще больше. Главные сотрудники - Н. В. Альбертини, В. П. Безобразов, В. И. Модестов, Е. Л. Марков, Г. К. Градовский, А. Д. Градовский, Е. Краевский, Л. А. Полонский и др. (см.: Энциклопедическій словарь Брокгауза и Ефрона: в 82 т. + 4 доп. СПб.: Семеновская Типолитографія (И. А. Ефрона), 1891. Т. IX (17). С. 108).

С. 71. Печальный конецъ Зари... - Журнал не был поддержан публикой и с трудом протянул до 1872 года благодаря В. В. Кашпиреву, потратившему на него свое состояние. Из-за недостатка подписчиков журнал перестал издаваться.

С. 71. ...иаритъ Зло свютсловской духъ «Дьла»... - Пародийная аллюзия фамилии главного редактора журнала «Дело» Г. Е. Благосветлова.

С. 71. ...помпщены превосходные очерки Мещерскаго «Наши Бисмарки».. - Владимир Петрович Мещерский (1839-1914) — основатель журнала «Гражданин» (издавался: 1872-1879, 
1882-1914; с перерывами). Редакторами-издателями журнала были: в 1872 году Г. К. Градовский, с 1873 по апрель 1874 гг. - Ф. М. Достоевский, в 1874-1879 гг. В. Ф. Пуцыкович, с 1882 года - снова Мещерский и др. (см.: Мещерскій В. П. Мои воспоминанія. Ч. 2 (1865-1881 гг.). СПб.: Типографія князя В. П. Мещерскаго, 1898. С. 157-182; см. также: [6]).

Сатирический роман Мещерского «Один из наших Бисмарков», печатавшийся в «Гражданине» в 1872 году (№№ 9-28) и в 1873 году (№№ 1, 3, 7, 11, 17, 19, 20), пользовался успехом. В 1874 году роман выдавался годовым подписчикам «Гражданина» по удешевленной цене (Д30, 21, 373). Достоевский, отмечая интерес публики к беллетристическим произведениям В. П. Мещерского и его талант, предрекал непродолжительность его популярности (5-6 лет) (см.: [3, 61]; см. также: Өедоръ Михайловичъ Достоевскій въ воспоминаніяхъ типографскаго наборщика въ 1872-1881 гг. // Русская Старина. 1892. Май. С. 306).

С. 72. ...рыиарямъ свистопляски въ родю Буренина и Суворина... - Буренин Виктор Петрович (1841-1926) - поэт и журналист. Литературное творчество начал с юмористических куплетов в «Искре» (1862) и «Современнике» (1863). Сотрудничал с «Отечественными Записками» редакции Некрасова, где напечатал ряд пьес, переводных и оригинальных, и юмористических стихотворений-пародий. Публиковался под псевдонимами: «Владимир Монументов», «Выборгский пустынник», «Z», «Граф Алексис Жасминов». Начиная с 1865 года посвятил себя газетной деятельности, работая в качестве одного из сотрудников «Санкт-Петербургских Ведомостей» редакции В. Ф. Корша и в течение 10 лет делая обзоры «Журналистики» с подписью «Z». В сотрудничестве с А. Сувориным написал драматическое произведение «Медея» (см.: Энциклопедическій словарь Брокгауза и Ефрона: в 82 т. + 4 доп. СПб.: Семеновская Типолитографія (И. А. Ефрона), 1891. Т. V (9). C. 22).

Суворин Алексей Сергеевич (1834-1912) - журналист. Переселившись в СанктПетербург в 1863 году, писал обозрение журналов в «Русском Инвалиде» с подписью А. И-н) и стал секретарем и ближайшим сотрудником «Санкт-Петербургских Ведомостей» при В. Корше. Здесь им был опубликован ряд полубеллетристических очерков под псевдонимом «А. Бобровский». Своими фельетонами, в которых обсуждались различные стороны государственной, общественной и литературной жизни, «наносил удары» по М. Н. Каткову, В. Д. Скарятину, В. П. Мещерскому. Фельетоны под псевдонимом «Незнакомец» имели большой успех. После вынужденного ухода в 1874 году из «С.-Петербургских Ведомостей» продолжил свою деятельность в «Новом Времени», считаясь его официальным издателем. Впоследствии Суворин, известный ранее и в качестве театрального рецензента, отошел от публицистики, занявшись вплотную театральной деятельностью: стал драматургом («Татьяна Репина», «Медея», «Биржевая горячка», «Не пойман, не вор», «Он в отставке» и др.) и возглавил литературно-артистический кружок (см.: [2, $394-396])$.

С. 72. ...я не совспмъ доволенъ только статьями о судебной ребормп и присяжныхъ... «Основные положения преобразования судебной части в России» были опубликованы 3 октября 1862 года, новые судебные уставы — в ноябре 1864 года (см.: Судебные уставы 20 ноября 1864 года, съ изложеніемъ разсужденій, на коихъ они основаны. СПб.: Изд. Гос. канцеляріи, 1866-1867. Часть первая-четвертая). В результате судебной реформы в России были учреждены суды, не зависящие от администрации, уничтожены сословные суды и введен институт присяжных заседателей. Внимание Достоевского к суду присяжных, за деятельностью которого писатель следил в 1870-е годы, усилилось в связи со слухами о возможном введении имущественного и образовательного ценза для присяжных 
заседателей, проверки благонадежности кандидатов. Сторонницей этих нововведений активно выступала газета «Русский Мир». По мнению Достоевского, после судебной реформы теория воздействия среды на формирование личности человека («среда заела») стала оказывать негативное влияние на присяжных заседателей, чему он и посвятил специальную главу «Дневника Писателя» - «Среда» (см.: Д30, 21, 385-387).

С. 72. ...значеніе суда присяжныхъ гораздо шире и многостороннпе, чпмъ Вы его понимаете - я сужу по Вашей статью... - Имеется в виду глава «Среда» в «Дневнике Писателя» Ф. М. Достоевского, впервые опубликованная в «Гражданине» в № 2 от 8 января 1873 года.

С. 72. ...Коллегія коронныхъ судей... - Коронные судьи - постоянные судьи, назначаемые императором, в отличие от присяжных заседателей, выбираемых для определенного судебного процесса. Занимаясь судебной деятельностью, коронные судьи не могли иметь иных должностей (см.: [4, 944-952]).

С. 72. Возымите напр. наши Волостные Cyды... - В каждой волости после освобождения крестьян был учрежден выборный волостной суд, разбиравший мелкие иски. Суд подчинялся не общему законодательству, а местным обычаям. К процедуре судейства и к самим судьям не предъявлялось никаких требований. Максимальное наказание ограничивалось 20 сутками ареста, поэтому правонарушители из числа крестьян находились в более выгодном положении, чем другие сословия.

С. 73. ... тамъ, гдю Окружные Суды не молотятъ дюла какъ горохъ... - Окружные суды, объединяющие несколько уездов (округ суда), рассматривали более серьезные гражданские и уголовные дела и состояли из профессиональных постоянных (коронных) судей (см.: $[4,944-952])$.

С. 74. ...Павлу Александровичу Матвпеву... - Матвеев Павел Александрович (род. 1844[?]) окончил курс на юридическом факультете Харьковского университета, служил товарищем прокурора в орловском окружном суде, делопроизводителем комитета для составления положений по преобразованию духовно-судебной части, был членом самарского окружного суда, советником дирекции правосудия в Восточной Румелии. Впоследствии состоял цензором в Санкт-Петербурге (с 1889 года). Вел литературную деятельность в «С.-Петербургских Ведомостях» В. Ф. Корша, являлся сотрудником «Журнала Министерства Юстиции», «Судебного Вестника», «Зари», «Русской Речи», аксаковской «Руси» и др. Избран секретарем комиссии при Императорском Географическом Обществе для изучения народных юридических обычаев. Составил проект программы для их собирания, редактировал VIII т. «Записок» этого общества (по отделу этнографии), за что награжден золотой медалью (1871). Публиковал статьи в «Русском Вестнике», «Историческом Вестнике» и др. В 1895 году опубликовал «Письма о литературе» под псевдонимом «Ачкасов» (см.: Энциклопедическій словарь Брокгауза и Ефрона: в 82 т. + 4 доп. СПб.: Семеновская Типолитографія (И. А. Ефрона), 1896. T. XVIIIa (36). С. 779).

\section{СПИСОК ЛИТЕРАТУРЫ}

1. Б. Г. Краевскій, Андрей Александровичъ / Б. Г. // Энциклопедическій словарь Брокгауза и Ефрона : в 82 т. +4 доп. - СПб. : Семеновская Типолитографія (И. А. Ефрона), 1895. - T. XVIa (32). - C. 483-484.

2. Венгеровъ, С. Суворинъ (Алексъй Сергъевичъ) / С. Венгеровъ // Энциклопедическій словарь Брокгауза и Ефрона : в 82 т. +4 доп. - СПб. : Семеновская Типолитографія (И. А. Ефрона), 1901. - Т. XXXIa (62). - С. 394-396. 
3. Воспоминания и исследования о творчестве Ф. М. Достоевского. Книга первая / М. А. Александров, В. Г. Авсеенко, Х. Д. Алчевская, Ю. И. Айхенвальд, П. В. Анненков и др. - Москва-Берлин : Директ-Медиа, 2015. - 367 с.

4. Лыкошинъ, А. С. Судоустройство / А. С. Лыкошинъ // Энциклопедическій словарь Брокгауза и Ефрона : в 82 т. +4 доп. - СПб. : Семеновская Типолитографія (И. А. Ефрона), 1901. - Т. XXXIa (62). - С. 944-952.

5. Неизвестные автобиографии А. А. Тихонова-Лугового, Н. Н. Страхова, Д. И. Стахеева и А. М. Скабичевского / публ. Л. С. Кишкина // Русская литература. - 1976. № 1. - С. $192-197$.

6. Пронина, И. А. Последний год «Гражданина» : К истории отношений правительственной цензуры и консервативной печати / И. А. Пронина // Вестник Волгоградского государственного университета. - Сер. 4 : История. Регионоведение. Международные отношения. - 2006. - № 11. - С. 23-30.

Подготовка текста Е. Н. Вяль, примечания Л. В. Алексеевой 